\title{
Coronary revascularisation in a patient with dextrocardia with situs inversus
}

\author{
MS Siddiqi \\ From 23rd World Congress of the World Society of Cardio-Thoracic Surgeons \\ Split, Croatia. 12-15 September 2013
}

\section{Background}

A few cases of CABG surgery in patients with dextrocardia and situs inversus have been reported so far worldwide. This is the first reported case of CABG surgery, in patient with dextrocardia and situs inversus performed in Middle East.

\section{Methods}

The surgery was done with surgeon standing on the left side. Vessels revascularized included the right internal mammary artery to the left anterior descending artery, the saphenous vein to the diagonal artery and to the obtuse marginal artery.

\section{Results}

The patient was discharged to his home after 12 days post operative with no complication. He was doing well after 3 months of follow-up.

\section{Conclusions}

Performing a coronary artery bypass surgery in patient with dextrocardia and situs inverses is a challenging case, in the fact it may be technically more demanding. However, it can be performed with success in same manner CABG is preformed in a non-dextrocardia patient if adequate modifications are made during surgery.
Published: 11 September 2013

doi:10.1186/1749-8090-8-S1-P35

Cite this article as: Siddiqi: Coronary revascularisation in a patient with dextrocardia with situs inversus. Journal of Cardiothoracic Surgery 20138 (Suppl 1):P35.
Correspondence: salmansiddiqi007@hotmail.com

Department of Cardiothoracic Surgery, Sultan Qaboos University Hospital, Muscat, Oman
Submit your next manuscript to BioMed Central and take full advantage of:

- Convenient online submission

- Thorough peer review

- No space constraints or color figure charges

- Immediate publication on acceptance

- Inclusion in PubMed, CAS, Scopus and Google Scholar

- Research which is freely available for redistribution

\section{() Biomed Central}

